УДК 349.2

DOI https: / / doi.org/10.32837 / yuv.v0i1.2083

\author{
Г. Чанишева, \\ доктор юридичних наук, професор, \\ декан соціально-правового факультету \\ Національного університету «Одеська юридична академія» \\ О. Щукін, \\ кандидат юридичних наук, \\ доцент кафедри трудового права та права соціального забезпечення \\ Національного університету «Одеська юридична академія»
}

\title{
ОЗНАКИ ТРУДОВИХ ВІДНОСИН ЗА АКТАМИ МОП I ЗАКОНОДАВСТВОМ УКРАЇНИ
}

\begin{abstract}
Постановка проблеми. Визначення ознак трудових відносин $€$ одним із концептуальних питань науки трудового права. Ознаки трудових відносин мають знаковий характер, оскільки фактично свідчать про самостійність галузі трудового права. Чітке визначення ознак трудових відносин має важливе теоретичне i практичне значення. Це передусім необхідно для розмежування трудових відносин від цивільних, оскільки існують спільні риси між трудовим договором і суміжними цивільноправовими договорами, пов'язаними 3 працею (договором підряду, договором надання послуг та ін.). Так, на практиці укладений договір підряду іменується трудовою угодою, але це не змінює правову природу зазначеного договору, який $€$ цивільно-правовим, а відносини, що виникають на підставі його укладення, регламентується нормами цивільного права.

Це питання останнім часом набуло особливої актуальності через висловлювання в літературі міркувань про те, що в перспективі трудовий договір трансформується в різновид цивільноправового договору і, відповідно, всі
\end{abstract}

трудові відносини будуть регулюватися нормами цивільного права.

Утім, у цей час визначення ознак трудових відносин має значення вже не тільки для відмежування їх від цивільних відносин. Із поширенням нетипових форм зайнятості відбувається модифікація ознак трудових відносин, окремі з них взагалі втрачають сенс, у зв'язку із чим необхідно чітко визначити саме ті ознаки зазначених відносин, які є ключовими (або традиційними) незалежно від форми організації праці.

Міжнародна організація праці приділяє велику увагу визначенню ознак трудових відносин. Конкретні ознаки зазначених відносин сформульовані у Рекомендації МОП №198 про трудове правовідношення 2006 року [1].

Ураховуючи зазначене, актуальним питанням сучасної науки трудового права $є$ визначення ознак трудових відносин з урахуванням положень Рекомендації МОП №198 та їх закріплення у чинному національному трудовому законодавстві, проекті Трудового кодексу України.

Аналіз останніх досліджень та публікацій. У сучасній науці трудового права ознаки трудових 
відносин (правовідносин) досліджуються вітчизняними i зарубіжними науковцями: M.I. Іншиним, M.В. Лушніковою, А.М. Лушніковим, Н.Л. Лютовим, К.Ю. Мельником, О.Т. Панасюком, П.Д. Пилипенком, С.М. Прилипком, I.А. Римарем, Я.В. Сімутіною, Д.В. Сичовим, С.М. Черноус, О.М. Ярошенком та ін.

Водночас у наукових працях відомих науковців недостатньо уваги приділено аналізу законодавчого закріплення ознак трудових відносин з урахуванням норм Рекомендації МОП № 198 про трудове правовідношення 2006 року, внесенню теоретично обгрунтованих пропозицій щодо його вдосконалення. Потребують правової оцінки й внесені зміни до ст. 21 чинного Кодексу законів про працю України (далі - КЗпП України), пов'язані з визначенням ознак трудового договору, а, відповідно, й ознак трудових відносин.

Метою статті $€$ визначення ознак трудових відносин з урахуванням положень Рекомендації МОП №198 і внесення пропозицій щодо закріплення зазначених ознак у чинному КЗпП України, проекті Трудового кодексу України.

Виклад основного матеріалу дослідження. У науці трудового права традиційно ознаки трудових відносин пов'язувалися і пов'язуються з ознаками трудового договору. Такий підхід вперше запропонував Л.С. Таль [2, с. 80-90], висновки якого отримали подальший розвиток у роботах таких класиків трудового права, як М.Г. Александров [3] і Л.Я. Гінцбург [4]. Вчені виокремили особистісну, організаційну та майнову ознаки трудових правовідносин і розглядали їх у нерозривній єдності.

У сучасній науковій літературі виділяються загальні та специфічні ознаки трудового правовідношення. До загальних ознак віднесені ті, що $€$ спільними 3 іншими правовідносинами. Перелік специфічних ознак трудового правовідношення не $є$ уні- фікованим. Так, науковці кафедри трудового права Національного юридичного університету імені Ярослава Мудрого специфічними ознаками трудового правовідношення вважають такі: воно виникає тільки з початком роботи за трудовим договором; трудове правовідношення $є$ індивідуальним; його суб'єктами є працівник і роботодавець; юридичним змістом його $€$ сукупність прав та обов'язків суб'єктів; робота виконується за певною професією, спеціальністю, кваліфікацією, посадою; працівник підпорядковується внутрішньому трудовому розпорядку; працівник виконує міру праці; оплата праці провадиться на підставах, визначених законодавством, локальним регулюванням і договором сторін [5, с. 15].

Узагальнюючи ознаки трудових правовідносин, учені виокремлюють такі ї елементи, як організаційно-трудовий, майновий (відплатний) і особистісний [5, с. 16].

O.T. Панасюк пропонує виокремлювати ознаки трудових відносин традиційно постійні, які з часом залишаються майже незмінними, та ті, які $€$ умовно новими, набуті через сучасні зміни [6, с.13]. Традиційно постійними вчений вважає такі: 1) виконання трудової функції працівником; 2) підпорядкування внутрішньому трудовому розпорядку; 3) включення до трудового колективу.

Характеризуючи типові характеристики трудових відносин, О.Т. Панасюк вважає за доцільне ставити питання про існування двох моделей трудових відносин: типової та нетипової. Нетипова модель трудових відносин відбиває зміни в суспільній організації праці та має вияв у таких організаційних формах, як дистанційна праця, залучення «квазіпрацівників» тощо [6, с. 17].

Поширення нетипової моделі трудових відносин супроводжується модифікацією ознак традиційних трудових правовідносин, а саме модифікацією їх організаційного елементу. 
Це проявляється, зокрема, в тому, що, наприклад, при дистанційній праці організація робочого місця може бути покладена як на роботодавця, так і на працівника; істотно знижується (або взагалі відсутній) контроль роботодавця за виконанням працівником своїх трудових обов'язків; змінюються можливості роботодавця щодо накладення дисциплінарних стягнень на працівника тощо.

У Рекомендації №198 МОП рекомендується державам-членам передбачити чітке визначення умов, що застосовуватимуться для встановлення факту існування трудового правовідношення, наприклад таких, як підлягання або залежність.

МОП зобов 'язує держави-члени передбачити можливість визначення у своїх законодавчих та інших нормативно-правових актах або іншими засобами конкретних ознак існування трудового правовідношення. Відповідно до п. 13 Рекомендації МОП №198 до таких ознак могли б бути віднесені такі елементи:

1) той факт, що робота виконується згідно з вказівками і під контролем іншої сторони; передбачає інтеграцію працівника в організаційну структуру підприємства; виконується виключно або головним чином в інтеpecax іншої особи; виконується особисто працівником; виконується відповідно до певного графіку або на робочому місці, що зазначається або узгоджується стороною, яка замовила iі; має певну тривалість і припускає певну наступність; вимагає присутності працівника; передбачає надання інструментів, матеріалів і механізмів стороною, яка замовила роботу;

2) періодична виплата винагороди працівнику: той факт, що дана винагорода $є$ єдиним або основним джерелом доходів працівника; здійснення оплати праці у натуральному виразі шляхом надання працівнику, наприклад, харчових продуктів, житла або транспортних засобів; визнання таких прав, як щотижневі вихідні дні і щорічні від- пустки; оплата стороною, яка замовила проведення робіт, поїздок, що здійснюються працівником в цілях виконання роботи; або те, що працівник не несе фінансового ризику [1].

На нашу думку, до конкретних ознак трудових правовідносин варто віднести такі: 1) об'єктом трудових правовідносин $є$ жива праця, надання у розпорядження роботодавця робочої сили, а їх сторонами - найманий працівник і роботодавець; 2) працівник виконує роботу за обумовленою трудовою функцією, тобто за конкретною посадою, спеціальністю, кваліфікацією, а не конкретно визначений обсяг робіт як у цивільних правовідносинах; 3) працівник включається до складу трудового колективу підприємства (установи, організаціi); 4) працівник виконує роботу відповідно до вказівок і під контролем роботодавця з підляганням внутрішньому трудовому розпорядку; 5) робота виконується особисто працівником виключно або головним чином в інтересах роботодавця на визначеному працівникові робочому місці, на якому вимагається його присутність, із наданням працівнику необхідних для роботи засобів (інструментів, матеріалів, механізмів тощо); 6) на роботодавця покладені обов'язки організувати процес праці та забезпечувати належні, безпечні та здорові умови праці, необхідні для виконання роботи; 7) у трудових правовідносинах регламентується тривалість робочого часу та встановлюються норми праці; 8) працівникові періодично (у встановлені колективним договором або трудовим договором строки) виплачується заробітна плата, яка $€$ єдиним або основним джерелом його доходів, у розмірі, не нижче мінімальної заробітної плати; 9) для трудових правовідносин характерний триваючий характер існування, тобто виконання сторонами своїх обов'язків стосовно один одного не припиняє зазначені правовідносини; 10) на працівника поширюються гарантії та пільги, передбачені 
трудовим законодавством, іншими нормативно-правовими актами, що містять норми трудового права, колективними договорами і колективними угодами (надання щорічної відпустки, вихідних, святкових і неробочих днів, оплата надурочної роботи тощо); 11) у трудових правовідносинах працівник не несе фінансового ризику при виконанні роботи; 12) у трудових правовідносинах роботодавець бере участь у фінансуванні соціального страхування працівника.

У Рекомендації МОП №198 зазначається, що концепція трудових відносин $є$ однаково присутньою в усіх правових системах і традиціях, хоча зобов'язання, права та пільги, пов'язані з трудовими відносинами, варіюються залежно від країни. Критерії, якими визначається реальне існування трудових відносин, також можуть варіюватися, навіть незважаючи на те, що у багатьох країнах застосовуються такі загальні для усіх поняття, як залежність і підлягання. Однак незалежно від критеріїв, що застосовуються, уряди, роботодавці та працівники поділяють прагнення для забезпечення того, щоб такі критерії були досить чітко сформульовані задля того, щоб легше було визначити сфери застосування різного законодавства, і щоб воно охоплювало саме тих осіб, яких воно покликано охоплювати, тобто осіб, які перебувають у трудових відносинах.

МОП виходить із правової презумпції існування індивідуального трудового правовідношення в тому випадку, коли визначено наявність однієї або декількох відповідних ознак. У п. 11 Рекомендації МОП № 198 ідеться про те, що в цілях сприяння визначенню існування індивідуального трудового правовідношення держави-члени повинні в рамках своєї національної політики розглянути можливість:

1) виділення більш широкого набору засобів для визначення існування трудового правовідношення;
2) встановлення правової презумпціï існування індивідуального трудового правовідношення у тому разі, коли визначено наявність однієї або декількох відповідних ознак;

3) визначення, на підставі попередніх консультацій з найбільш представницькими організаціями роботодавців і працівників, що працівники, які мають певні характеристики, повинні в цілому або в рамках окремого сектору вважатися або найманими працівниками, або самостійно зайнятими працівниками.

Сучасні вітчизняні дослідники вносять пропозиції щодо законодавчого закріплення основних ознак трудових правовідносин відповідно до положень Рекомендації МОП № 198. Так, Я.В. Сімутіна пропонує передбачити у проекті Трудового кодексу України такі основні ознаки трудових відносин: по-перше, це підконтрольність i підпорядкування працівника роботодавцю; по-друге, це економічна залежність від роботодавця; по-третє, працівник особисто виконує роботу, і це триває протягом певного періоду [7, c. 8].

У науці трудового права також пропонується закріпити в проекті Трудового кодексу України правову презумпцію існування індивідуальних трудових відносин, коли встановлено наявність декількох відповідних ознак (наприклад, таких, як підлеглість або залежність працівника) [8, с. 167].

У чинному КЗпП України відсутні визначення як поняття трудових відносин, так і переліку їх ознак. Окремі 3 них можна виділити тільки із поняття трудового договору, закріпленого в частині першій ст. 21 Кодексу, відповідно до якої трудовим договором $є$ угода між працівником і власником підприємства, установи, організації або уповноваженим ним органом чи фізичною особою, за якою працівник зобов'язується виконувати роботу, визначену цією угодою, а власник підприємства, установи, організації або уповноважений ним орган чи фізична 
особа зобов'язується виплачувати працівникові заробітну плату і забезпечувати умови праці, необхідні для виконання роботи, передбачені законодавством про працю, колективним договором і угодою сторін.

Законом України «Про внесення змін до деяких законодавчих актів України, спрямованих на забезпечення додаткових соціальних та економічних гарантій у зв'язку з поширенням коронавірусної хвороби (COVID-19)» від 30 березня 2020 року № 540 [9] статтю 21 КЗпП України було викладено в новій редакції. Із частини першої зазначеної статті була виключена така ознака трудового договору, як підлягання працівника внутрішньому трудовому розпорядку.

Виключення зазначеної ознаки пояснюється тим, що Законом України від 30 березня 2020 року було викладено в новій редакції i ст. 60 КЗпП України (з одночасною зміною їі назви), нормами якої врегульовані такі форми організації праці, як гнучкий режим робочого часу i дистанційна (надомна) робота. Не аналізуючи зміст зазначених норм, слід звернути увагу на те, що у визначенні поняття гнучкого режиму робочого часу в частині третій ст. 60 законодавець вказує на відмінності цього режиму від визначеного правилами внутрішнього трудового розпорядку, а в частині одинадцятій цієї статті зазначає про те, що «при дистанційній (надомній) роботі працівники розподіляють робочий час на свій розсуд, на них не поширюються правила внутрішнього трудового розпорядку, якщо інше не передбачено у трудовому договорі». В останньому випадку логіку законодавця складно зрозуміти, оскільки цим самим Законом, як вже відзначалося, із частини першої статті 21 Кодексу із поняття трудового договору було вилучено слова «3 підляганням внутрішньому трудовому розпорядку». Але як випливає зі змісту частини одинадцятої ст. 60 КЗпП України, законодавець одночасно визнає наявність і дію правил внутрішнього трудового розпорядку. Крім того, Законом України від 30 березня 2020 року не було внесено змін до ст. 142 «Правила внутрішнього трудового розпорядку. Статути і положення про дисципліну» КЗпП України, в частині першій якої закріплено імперативну норму про те, що Трудовий розпорядок на підприємствах, в установах, організаціях визначається правилами внутрішнього трудового розпорядку. Отже, наявною $€$ колізія між частиною першою ст. 21 КЗпП України, в якій визначається поняття трудового договору, і ст. 142 цього Кодексу, що закріплює загальну норму про правила внутрішнього трудового розпорядку.

Отже, склалася ситуація, коли при встановленні спеціальних норм, що врегульовують окремі форми організації праці, законодавець допустив зміну загальної норми, якою визначено поняття трудового договору, а відтак і ознаки трудових відносин, про що йшлося вище. Таке законодавче рішення справедливо підверглося критиці в літературі. Так, С.М. Черноус слушно зауважує, що, по-перше, існування різних форм організації праці не впливає на сутнісні характеристики трудових правовідносин, яким притаманна вся сукупність так званих «традиційно постійних» ознак; по-друге, виникнення нових форм організації праці не змінює правової природи трудових відносин; по-третє, встановлення спеціального правила поведінки (норми) не скасовує загального [10, с. 42].

Відсутність у чинному КЗпП України спеціальних норм про трудові відносини $€$ його суттєвим недоліком. У частині першій ст. 1 Кодексу йдеться про те, що «Кодекс законів про працю України регулює трудові відносини всіх працівників», але у Кодексі не визначаються поняття та ознаки трудових відносин, їх сторони, підстави виникнення тощо. 
Проект Закону України «Про внесення змін до деяких законодавчих актів України щодо посилення трудових прав працівників та протидії застосуванню незадекларованої праці» [11], опублікований у 6 лютого 2019 року на офіційному веб-сайті Міністерства соціальної політики України, мав за мету усунути прогалини у чинному КЗпП України щодо закріплення поняття трудових відносин та ознак ї наявності. Статтю 21 Кодексу пропонувалося іменувати «Трудові відносини», в частині першій зазначеної статті визначалося поняття трудових відносин, а в частині першій ст. 21-2 законопроекту закріплювалася презумпція наявності трудових відносин, якщо є три і більше із семи передбачених у цій статті ознак.

Зазначений законопроект одразу був підданий критиці, особливо з боку представників галузі IT в Україні [12]. Однак насправді ніякої загрози існуванню галузі IT цей законопроект не представляв. На нашу думку, законопроект дійсно мав за мету посилення захисту трудових прав працівників і боротьбу з незадекларованою працею. Він не був спрямований на заміну цивільно-правових договорів (підряду, надання послуг та ін.) трудовим договором, а цивільних правовідносин трудовими правовідносинами, оскільки, як вже відзначалося вище, кожен 3 названих видів правовідносин має свої юридичні ознаки, які необхідно чітко визначити і закріпити на законодавчому рівні. Але законопроект так і не був прийнятий.

Водночас зазначений законопроект не можна визнати вдалим з точки зору усунення прогалин у КЗПП України шляхом його доповнення спеціальними нормами про трудові відносини. Ці норми пропонувалося закріпити в главі III «Трудовий договір», в назві якої не йдеться про трудові відносини. Не можна погодитися зі зміною назви статті 21 «Трудовий договір» на «Трудові відносини», оскільки це має бути окрема стаття в Кодексі. Заслуговує на увагу зазначений вище зміст статті 21-2, але тільки цих двох статей явно недостатньо для усунення зазначених прогалин. У зв'язку з цим видається доцільним доповнити чинний КЗпП України окремою главою 1-1 «Трудові відносини», нормами якої закріпити поняття та ознаки трудових відносин, презумпцію їх існування за наявності декількох ознак, сторони трудових відносин, їх основні трудові права і обов'язки, підстави виникнення трудових відносин.

Прогалини у чинному КЗпП України частково усуваються у проекті Трудового кодексу України [13], до якого включено окрему Книгу другу «Виникнення та припинення трудових відносин. Трудовий договір». У частині першій ст. 30 «Виникнення трудових відносин» законопроекту визначається поняття трудових відносин як відносин між працівником і роботодавцем, що передбачають виконання особисто працівником за винагороду визначеної роботодавцем роботи (трудової функціі) в інтересах, під керівництвом та контролем роботодавця з обов'язковим додержанням працівником правил внутрішнього трудового розпорядку при забезпеченні роботодавцем належних, безпечних та здорових умов праці.

На нашу думку, окремі положення запропонованого визначення потребують уточнення і змін. Так, у визначенні йдеться про «винагороду», але для трудових відносин властивою є категорія «заробітна плата» як одна із ознак їх наявності. У визначенні не вказується про те, що трудові відносини є відносинами, що виникають на підставі угоди між працівником і роботодавцем, оскільки найбільш поширеною підставою їх виникнення є саме трудовий договір як угода між працівником і роботодавцем. Тому не можна погодитися 3 позицією розробників проекту Трудового кодексу України, що трудові відносини передбачають виконання працівником «визначеної 
роботодавцем роботи (трудової функціi)», оскільки ця робота (трудова функція) визначається угодою сторін, а не роботодавцем в односторонньому порядку.

У визначенні трудових відносин зазначається про «обов'язкове додержання працівником правил внутрішнього трудового розпорядку». Слово «обов'язкове» викликає заперечення, оскільки вище вже йшлося про форми організації праці, за яких виконання роботи працівником не передбачає додержання ним правил внутрішнього трудового розпорядку. Тому слово «обов'язкове» варто виключити із поняття трудових відносин.

Також у частині першій ст. 30 ідеться про забезпечення роботодавцем належних, безпечних та здорових умов праці. На нашу думку, формулювання цього обов'язку роботодавця потребує уточнення шляхом зазначення про те, що ці умови праці передбачені трудовим законодавством, колективним договором, угодами, трудовим договором.

На відміну від попередніх законопроектів, частину першу ст. 30 проекту Трудового кодексу України № 2410 від 08.11.2019 доповнено важливими положеннями про ознаки трудових відносин. Передбачається, що трудовими відносинами є відносини, відповідно до яких працівник виконує певну роботу в інтересах роботодавця незалежно від форми домовленості про це, за наявності трьох і більше ознак:

1) особисте виконання працівником трудової функції (роботи за посадою відповідно до штатного розкладу, професії, спеціальності з вказівкою на кваліфікацію; конкретний вид роботи, що доручається працівникові) за вказівкою та під контролем роботодавця;

2) робота виконується за визначеним роботодавцем графіком або правилами внутрішнього трудового розпорядку;

3) робота виконується на визначеному або погодженому 3 роботодавцем робочому місці;
4) працівник виконує роботи подібні до роботи, що виконується штатними працівниками роботодавця;

5) організація умов праці, зокрема надання засобів виробництва (обладнання, інструментів, матеріалів, сировини) забезпечується роботодавцем;

6) тривалість робочого часу та часу відпочинку встановлюється роботодавцем;

7) періодично (два і більше разів на місяць) працівникові надається винагорода за роботу, виконувану в інтересах роботодавця;

8) винагорода за виконану роботу $€$ єдиним джерелом доходу працівника або становить 75 і більше відсотків його доходу протягом шести календарних місяців сумарно на рік.

На нашу думку, перелік ознак трудових відносин, який пропонується закріпити у частині першій ст. 30 проекту Трудового кодексу України, потребує доповнення з урахуванням положень п. 13 Рекомендації МОП про трудове правовідношення 2006 року. Ідеться про такі ознаки, як: інтеграція працівника в організаційну структуру підприємства; виконання роботи виключно або головним чином в інтересах іншої особи; працівник не несе фінансового ризику при виконанні роботи.

У частині першій ст. 30 законопроекту також закріплено важливу норму про те, що укладення цивільно-правових договорів, що фактично регулюють трудові відносини між працівником і роботодавцем, не допускається. Відповідна норма відсутня у КЗпП України. Зазначену норму також необхідно закріпити в чинному Кодексі.

Висновки. 3 метою імплементації положень Рекомендації МОП № 198 про трудове правовідношення від 31 травня 2006 року у національне трудове законодавство необхідно в окремій статті чинного КЗпП України закріпити поняття та перелік ознак трудових відносин. Потребує вдосконалення визначення поняття 
трудових відносин у частині першій ст. 30 проекту Трудового кодексу України.

Видається доцільним визначити трудові відносини як відносини, що виникають на підставі угоди між працівником і роботодавцем про особисте виконання працівником за своєчасну і в повному обсязі заробітну плату трудової функції (роботи за визначеною професією, спеціальністю, кваліфікацією, посадою) в інтересах, під керівництвом і контролем роботодавця 3 додержанням працівником правил внутрішнього трудового розпорядку при забезпеченні роботодавцем належних, безпечних та здорових умов праці, передбачених трудовим законодавством, колективним договором, угодами, трудовим договором.

Абзац другий частини першої ст. 30 проекту Трудового кодексу України пропонується викласти в такій редакціі: «Трудовими відносинами $є$ відносини, в яких працівник виконує роботу за визначеною трудовою функцією в інтересах роботодавця незалежно від назви та виду договору між сторонами, якщо є три і більше нижчезазначених ознак:

1) особисте виконання працівником трудової функції (роботи за визначеною професією, спеціальністю, кваліфікацією, посадою) в інтересах роботодавця;

2) робота виконується працівником під керівництвом і контролем роботодавця 3 додержанням правил внутрішнього трудового розпорядку;

3) виконання роботи передбачає інтеграцію працівника в організаційну структуру підприємства;

4) робота виконується на визначеному або погодженому $з$ роботодавцем робочому місці 3 визначенням режиму і тривалості робочого часу;

5) роботодавцем забезпечуються належні, безпечні та здорові умови праці (в тому числі надання засобів виробництва), передбачених трудовим законодавством, колективним договором, угодами, трудовим дого- вором (іншим договором між сторонами);

6) періодично (у встановлені строки, але не рідше двох разів на місяць) працівнику за виконану роботу виплачується заробітна плата;

7) заробітна плата є єдиним джерелом доходу працівника або становить 75 і більше відсотків доходу протягом шести календарних місяців сумарно на рік;

8) працівник не несе фінансового ризику при виконанні роботи.

У статті розглядаються ознаки трудових відносин за актами Міжнародної організації праці та законодавством України. Аналізуються норми Рекомендації МОП № 198 про трудове правовідношення від 31 травня 2006 року про ознаки зазначеного правовідношення.

Звертається увага на прогалини у чинному Кодексі законів про працюю України щцодо визначення поняття трудових відносин та ознак їх наявності. Пропонуеться доповнити чинний Кодекс окремою главою I з позначкою один (I ${ }^{1}$ «Трудові відносини», нормами якої визначити поняття та ознаки трудових відносин, презумпцію ї існування за наявності декількох ознак, сторони трудових відносин, їх основні трудові права і обов'язки, підстави виникнення зазначених відносин.

Доводиться необхідність закріплення у зазначеній главі окремої норми про презумпцію існування індивідуального трудового правовідношення при встановленні наявності декількох його ознак, передбачених Кодексом, та формулюється ї̈ зміст.

Аналізується зміст статmі 30 "Виникнення трудових відносин» проекту Трудового кодексу України. Вносяться пропозиції про внесення змін $i$ доповнень до зазначеної статті з урахуванням норм Рекомендації МОП № 198 про трудове правовінношення 2006 року. 
У Кодексі законів про працю України, проекті Трудового кодексу України пропонується визначити трудові відносини як відносини, що виникають на підставі угоди між працівником $i$ роботодавием про особисте виконання працівником за своєчасну $i$ в повному обсязі заробітну плату трудової функціі (роботи за визначеною професією, спеціальністю, кваліфікацією, посадою) в інтересах, під керівниитвом $і$ контролем роботодавия з додержанням працівником правил внутрішнього трудового розпорядку при забезпеченні роботодавием належних, безпечних та здорових умов праці, передбачених трудовим законодавством, колективним договором, угодами, трудовим договором.

Ключові слова: трудові відносини, ознаки трудових відносин, акти МОП, трудове законодавство України, проект Трудового кодексу України.

\section{Chanysheva G., Shukin O. Features of employment relationships according to ILO acts and legislation of Ukraine}

The article considers the features of employment relationships according to the acts of the International Labor Organization and the legislation of Ukraine. The norms of the ILO Recommendation № 198 on Employment Relationship of May 31, 2006 on the features of such legal relationships have been analyzed.

Attention is drawn to the gaps in the current Code of Laws on Labour of Ukraine in defining the concept of employment relationships and signs of their existence. It is proposed to supplement the current Code with a separate chapter $I^{t}$ Employment relationships, the rules of which define the definition and features of employment relationships, the presumption of their existence in the presence of several features, parties of employment relationships, their basic labor rights and responsibilities, the grounds of emergence of these relations.

The need to enshrine in this chapter of a separate rule on the presumption of existence of an individual employment relationship, establishing the presence of several of its features, provided by the Code, is substantiated, and its content is formulated.

The content of Article 30 Origin of employment relationships of the draft Labor Code of Ukraine has been analyzed. Proposals are made to amend this article, taking into account the provisions of ILO Recommendation № 198 on Employment Relationship of May 31, 2006.

It is proposed to define employment relationships in the Code of Laws on Labor of Ukraine, the draft Labor Code of Ukraine as relations arising on the basis of an agreement between the employee and the employer on personal performance by the employee for timely and full wages of the labor function (work in a particular profession, specialty, qualification, position) in the interests, under the guidance and control of the employer with the employee's compliance with the rules of internal labor regulations while providing the employer with proper, safe and healthy working conditions provided by labor legislation, collective agreement, covenants, employment contract.

Key words: employment relationships, features of employment relationships, ILO acts, labor legislation of Ukraine, draft Labor Code of Ukraine.

\section{Література}

1. Рекомендация МОт №198 о трудовом правоотношении от 31 мая 2006 года. Труд за рубежом. 2007. № 2. С. 152-160.

2. Таль Л.С. Трудовой договор. Цивилистическое исследование. Ч. 1. Ярославль, 1913

3. Александров Н.Г. Трудовое правоотношение. Москва : Изд-во МЮ СССР, 1948. $336 \mathrm{c}$ 


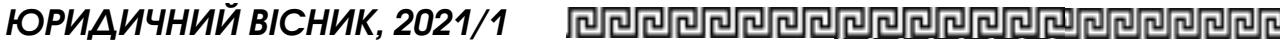

4. Гинцбург Л.Я. Социалистическое трудовое правоотношение. Москва : Наука, 1977. 310 c.

5. Трудове право : підручник /Әля студ. юрид. спец. вищ. навч. закл./ / В.В. Жернаков, С.М. Прилипко, О.М. Ярошенко та ін. ; за ред. В.В. Жернакова. Харків : Право, 2012. 496 с.

6. Панасюк О.T. Начатки трудового права. Лекція 2 «Поняття трудового права»: навчально-практичний посібник. Дніпропетровськ : Видавеиь Середняк T.K., 2016. 72 с.

7. Сімутіна Я.В. Юридичні факти в механізмі правового регулювання трудових відносин : автореф. дис. ... докт. юрид. наук : 12.00.05. Одеса, 2019. 40 c.

8. Чанишева Г.І. Правове регулювання індивідуальних трудових відносин: монографія. Одеса: Фенікс, 2016. 192 с.

9. Про внесення змін до деяких законодавчих актів України, спрямованих на забезпечення додаткових соиіальних та економічних гарантій у зв'язку з поширенням коронавірусної хвороби (COVID-19) : Закон України віо 30 березня 2020 року № 540-IX. Відо- мості Верховної Ради України. 2020. № $18 . \mathrm{Cm}$. 123 .

10. Черноус С.М. Про безпідставність перегляду ознак трудових правовідносин. Правове забезпечення соціальної безпеки в умовах євроінтегращійних процесів: тези допов. учасн. Міжн. наук.-практ. конф. (м. Київ, 06 листопада 2020 р.) / за ред. проф. М.I. Iншина. Київ : "Освіта України», 2020. 168 с.

11. Про внесення змін до деяких законодавчих актів України щодо посилення трудових прав працівників та протидії застосуванню незадекларованої праиі : проект Закону України, підготований Міністерством соиіальної політики України. URL: https://wшr.msp.gov.ua/ projects / 401 /? PrintVersion.

12. Нова загроза для ФОПів в IT: щз пропонуе Мінсоиполітики в новому законопроекті. URL: https://ain.ua/ 2019/02 / 14 / nova-zagroza-dlya-fopiv$v$-it/.

13. Проект Трудового кодексу України №2410 від 08.11.2019. URL: https: / / w1.c1.rada.gov.ua/pls / zweb2 / webproc4_1?pf3511=67331. 